\title{
Conservation and preservation of medicinal plants- leads from Ayurveda and Vrikshayurveda
}

\begin{abstract}
Traditional knowledge is vital for sustainability of natural resources including medicinal plants. Biodiversity conservation can be learnt from the context-specific local knowledge and intergenerational transmission of knowledge, skills and strategies, concern for well-being of future generations. Vrikshayurveda deals with various tree and plant species and ensure the healthy growth and productivity. The ancient text consists of about 170 different plant species including herbs, shrubs and trees. The different chapters of Vrikshayurveda deal with agri horticulture, home gardening, intercropping and storage etc. This paper intends to understand the traditional knowledge on biodiversity, particularly in the light of contemporary research on traditional and formal knowledge systems and demonstrate the value of traditional knowledge for biodiversity conservation with special reference to medicinal plants.
\end{abstract}

Keywords: traditional conservation, medicinal plants, vrikshayurveda, kunapajala

\author{
Volume II Issue 5 - 2018
}

Shubhashree MN, Shiddamallayya Matapathi, Amit Kumar Dixit

Regional Ayurveda Research Institute for Metabolic disorders, India

Correspondence: Shubhashree MN, Research Officer (S-2), Regional Ayurveda Research Institute for Metabolic disorders (RARIMD), Govt .Central Pharmacy Annexe, Near Ashoka Pillar, Jayanagar, Bangalore, Karnataka, India, Tel 9448016968 , Email shubhathijas@gmail.com

Received: April 20, 2018| Published: October 10, 2018

\section{Introduction}

Today, when people throughout the world are disturbed by the degradation of the environment and the disastrous consequences of this, traditional ethics of nature conservation could be looked upon as a source of inspiration and guidance for the future.

The traditions can be classified as

1. Religious traditions: temple forests, monastery forests, sanctified and deified trees

2. Traditional tribal traditions: sacred forests, sacred groves and sacred trees

3. Royal traditions: royal hunting preserves, elephant forests, royal gardens etc.

4. Livelihood traditions: forests and groves serving as cultural and social space and source of livelihood products and services

For instance, "Sacred groves' were dedicated to a deity or a village God, protected, and worshipped like Devarakaadu near Shimoga, India. The Sacred Groves are important repositories of floral and faunal diversity that have been conserved by local communities in a sustainable manner. They are present in Himachal Pradesh, Maharashtra, Kerala, Karnataka, and other places and highlight community managed conservation efforts. ${ }^{1}$ Historically, the protection of nature and wildlife was an ardent article of faith, reflected in the daily lives of people, enshrined in myths, folklore, religion, arts, and culture. Such traditional cultural attitudes, though based on religious faith, have made significant contribution in the protection and propagation of various species of trees and plants in India. ExUse of bael in summer associated with Ramanavami celebration, Durva for Lord Ganesha, Parijatha plant for Lord Krishna, Bilwa for Lord Ishwara and so on. For the people of India, environmental conservation is not a new concept. Sustainability was ingrained in the thought processes of early Indians as evident from the teachings of Vedas. Perhaps no other culture can provide such a profound variety of cultural practices and ecologically sound relationship with nature as the Indian. For eg: a hymn in Atharva Veda (12.1.35) says "Whatever I dig out from you, O Earth! May that have quick regeneration again, may we not damage thy vital habitat and heart. ${ }^{2}$ Implicit here are the following principles: In the process of harvest no damage should be done to the earth, Humans are forewarned not against the use of nature for survival, but against the overuse and abuse.

The practice of allocating tree species to individuals based on lunar asterism like nakshatra vana, navagraha vrukshas was also prevalent. Nakshatravana, Rashivana and Navagraha Vrukshas are other effective ideas to protect trees and environment. There has been a practice of allocating tree species to individuals based on lunar asterism under which they are born (birth star trees or Nakshatravanam) under this, all individuals are expected to take care of their birth star trees. ${ }^{3}$ They are

\section{Nakshatra vanam plants}

\begin{tabular}{llll}
\hline SI. No & Scientific name family & Nakshatram & Family \\
\hline Strychnos nux-vomica & Ashwini & Loganiaceae \\
Phyllanthus emblica( Emblica officinalis) & Bharani & Phyllanthaceae \\
Ficus racemosa & Kruttica & Moraceae \\
Syzygium cumini & Rohini & Myrtaceae \\
Acacia chundra & Mrugasira & Fabaceae \\
Gmelina arborea & Aardra & Verbinaceae \\
\hline
\end{tabular}


Table Continued....

\begin{tabular}{|c|c|c|c|}
\hline SI. No & Scientific name family & Nakshatram & Family \\
\hline & Bambusa bambos & Punarvasu & Poaceae \\
\hline & Ficus religiosa & Pushyami & Moraceae \\
\hline & Mesua ferrea & Ashlesha & Calophyllaceae \\
\hline & Ficus benghalensis & Makha & Moraceae \\
\hline & Butea monosperma & Purva Palguni & Fabaceae \\
\hline & Ficus virens & Uttara Palguni & Moraceae \\
\hline & Spondias pinnata & Hasta & Anacardiaceae \\
\hline & Aegle marmelos & Chitta & Rutaceae \\
\hline & Terminalia arjuna & Swathi & Combretaceae \\
\hline & Mimusops elengi & Anuradha & Sapotaceae \\
\hline & Symplocos cochinchinensis & Jyestha & Symplocaceae \\
\hline & Canarium strictum & Mula & Burseraceae \\
\hline & Barringtonia racemosa & Purvashada & Lecythidaceae \\
\hline & Artocarpus heterophyllus & Uttarashada & Moraceae \\
\hline & Calotropis gigantea & Sravana & Apocynaceae \\
\hline & Prosopis cineraria & Dhanista & Fabaceae \\
\hline & Neolamarckia cadamba & Shatabisham & Rubiaceae \\
\hline & Flacourtia indica & Vishaka & Salicaceae \\
\hline & Mangifera indica & Purvabhadra & Anacardiaceae \\
\hline & Azadirachta indica & Uttarabhadra & Meliaceae \\
\hline & Madhuca longifolia var. latifolia (Syn.M. indica) & Revathi & Sapotaceae \\
\hline
\end{tabular}

Mythology also has been useful in cultivating certain plants that mentions that one who grows Tulsi at home will be residing in Vaikunta needed extra care. Socio-culturally valued species find place in home gardens and courtyards For example, Tulsi (Ocimum sanctum) a highly valued medicinal plant is grown, in every household in centre of the courtyard and ritually watered even today. Vrikshayurveda (Heaven) for 1000 years. It is also said that one who plants neem and mango trees on roadsides would be attain liberation. Probably, these are counted as motivational factors for plant preservation based on mythology. ${ }^{4}$

\section{Navagraha Vruksha ${ }^{3}$}

\begin{tabular}{llll}
\hline Arka Plant/Milkweed Plant & Calotropis procera & (Sun) & Surya \\
Palasha Plant / Flame-of-the-forest Tree & Butea monosperma & $($ Moon $)$ & Chandra \\
Khadira & Acacia catechu & (Mars) & Kuja \\
Apamarga & Achyranthes aspera & Mercury & Budha \\
Durva & Cynodon dactylon & North Dode & Rahu \\
Ashwattha & Ficus religiosa & Jupiter & Guru \\
Kusa (Dharbe) & Eragrostis cynosuroides & South Dode & Ketu \\
Audumbara & Ficus glomerata & Venus & Shukra \\
Shami & Prosopis cineraria & Saturn & Shani
\end{tabular}

Several trees and shrubs were regarded as sacred because of their proximity to a particular deity ex- Doorva for Ganesha, Parijatha for medicinal/aesthetic/natural qualities as well as some because of their Lord Krishna, Bilwa for Lord Ishwara and so on.

\section{Rashivana $^{3}$}

\begin{tabular}{llll}
\hline SI.No & Zodiac sign & Botanical name & Common name \\
\hline & Aries(Mesha) & Pterocarpus santalinus & Red Sandalwood \\
& Taurus (Vrishabha) & Alstonia scholaris & Sapthaparni
\end{tabular}


Table Continued....

\begin{tabular}{llll}
\hline SI.No & Zodiac sign & Botanical name & Common name \\
\hline Gemini (Mithuna) & Artocarpus heterophyllus & Jack fruit tree \\
Cancer (Karkataka) & Butea monosperma & Palasha \\
Leo (Simha) & Stereospermum chelonoides & Kaligottu \\
Virgo(Kanya) & Mangifera indica & Mango \\
Libra(Tula) & Mimusops elengi & Pogada \\
Scorpio (Vruschika) & Acacia catechu & Khadira \\
Sagittarius (Dhanu) & Ficus religiosa & Peepal \\
Capricorn (Makara) & Dalbergia sissoo & Shisham \\
Aquarius (Kumbha) & Prosopis cineraria & Shami \\
Pisces (Meena) & Ficus benghalensis & Banyan \\
\hline
\end{tabular}

\section{Preservation principles in ancient texts}

Soil suitable for the cultivation and collection of drugs, proper identification, period of collection, seasons for collection, parts used, preservation methods etc. have been detailed in Ayurveda Siddha
\& Unani (ASU) literatures viz. Charaka Samhita, Susruta Samhita, Bhavaprakasha, Sharangadhara Samhita etc ${ }^{5}$ Science of Ayurveda advocates Sharad Ritu (i.e. October and November) as the best season for the harvesting of herbs for therapeutic purpose. ${ }^{6}$

\begin{tabular}{ll}
\hline Part of the plant specified for therapeutic use & Harvesting season \\
\hline Flowers & Spring \\
Fruits & Spring \\
Roots & Summer or in the late winter \\
Leaves and spring (early summer) & Rainy season and spring (early summer) \\
Branches & Rainy season \\
Bark & Early winter \\
Stem & Early winter \\
Latex & Early winter \\
Harvesting in general & Early winter \\
\hline
\end{tabular}

\section{Relevance of Vrikshayurveda}

Recognizing the significance of plant bio- resources of varied values in ancient India, emphasis has been laid on conservation of flora. Ancient texts contain many descriptions of the uses and management of forests and highlight sustainability as an implicit theme. Treatise called Vrikshayurveda mentions in depth about the plants, its importance, diseases suffered by them, treatment, protection from external factors, increasing the yield, conservation techniques like protection of plants from mist, pests etc. Chemical fertilizers show dramatic short-term benefits, but in the longer run they adversely impact the soil, water and perhaps the nutritional quality of the plants. ${ }^{7}$ Hence there is great scope to integrate traditional practices for better productivity of quality planting materials

The second chapter "Bijoptivithi" illustrated about the process of seed germination and explains about grading and preservation of seeds. The methods described for seed preservation is to mix the seeds with ashes and it was also suggested that the seeds should be exposed to the medicated smoke which can serve as an antimicrobial agent. Fertilizers are prescribed for undeveloped and underdeveloped trees and plants. Drumaraksa is the chapter deals with several advices to save plants and trees from the weather and other conditions like winds and storms. It also tells about the medicinal plants used on the broken branch to protect the whole tree from dying. Use of powders of Solanum indicum, Sesamum indicum, Embelia ribes and Brassica juncea, milk, ghee and cow dung has been mentioned in almost all the texts for protection during storage. ${ }^{8}$ In addition to pre treatments applicable to all seeds in general, treatments specific to specific plants also have been described. Various seed priming processes have been carefully designed in Vrikshayurveda to allow early germination, to obtain good quality of seedlings by following the classical techniques. A study conducted to compare the effects of Vrikshayurveda \& Modern cultivation techniques on germination of Bakuchi has revalidated the germination behaviour of dormant seeds of Psoralia corylifolia. ${ }^{9}$ The chapter "Citrikarana" depicts some astounding techniques such as to make a plant bloom throughout the year irrespective of the seasons, bring forth premature maturity to plants and fruits, and change the shape and form of trees. For nourishment of plants, use of a biofertilizer called 'Kunapajala' has been mentioned.

\section{Kunapajala as organic manure}

Kunapajala is a natural organic product derived from animal and plant products containing a significant quantity of one or more of the primary nutrients like Nitrogen, Phosphorus, and Potassium which are necessary for plant growth. The literary meaning of the Sanskrit word Kunapa is "smelling like a dead or stinking" and the name is 
apt for the liquid manure which is prepared using excreta, bones ,body, flesh and marrow of animals, fish, decayed plant products etc. Kunapajala has some plant growth regulatory actions through which it enhances the overall growth of plants. Being a liquid biofertilizer it is a more suitable form of manure and can be beneficial in growth of medicinal plants with probably minimal toxic effects on human body when compared to chemical fertilizer. Usually the raw organic matter decomposes into humus which will be further digested by soil microbes producing high levels of organic acids like humic, carbonic and fulvic acids and increases high cation $(+)$ exchange capacity. This capacity is responsible for the mobilization of calcium, potassium and other plant nutrients. In order to obtain good results aerobic composting is said to be beneficial.

The nitrogen which is very essential for plant growth is supplemented by blood, cottonseed, fish meal and emulsion etc, whereas compost from bird manures, bone meal etc are rich source of Phosphorus and Potassium which helps in regulating root, bud, flower and fruit formation, cell division, sugar formation in the sap, chlorophyll production and photosynthesis, increasing crop resistance to diseases etc. The other important micronutrients are Magnesium, Calcium, Zinc, Manganese, Copper, Iron, and Selenium which are also supplemented by the organic compost Kunapajala. ${ }^{10}$ Researchers suggest that application of the principles of Vrikshayurveda like Kunapajala does produce phenomenal and interesting results. Since few research works have been carried out, this discipline of science needs to be developed through concerted research efforts to ascertain its utility.

\section{Advantages of organic farming}

Though, chemical fertilizers increase the yield, they pose certain serious health threats to human beings especially infants, pregnant and nursing mothers. ${ }^{11}$ Another concern for health is contamination of medicinal plants with toxic heavy metals like mercury, lead, cadmium, etc., through fertilizers, harmful industrial wastes contaminating the water sources etc. In contrast, organic manures are considered to be safe and yielding good produce by improving water penetration, waterholding capacity, improvement in soil structure, microbial biomass, nutrient availability, drought and heat stress resistance. It also helps in improving the soil $\mathrm{pH}$ which has an impact on plant growth and soil microbial activity. ${ }^{10}$ Studies using Kunapajala for growing Senna ${ }^{12}$ have shown that the total Sennoside content per plant was more. Simlarly for Langali (Gloriosa superba Linn.) ${ }^{13}$ the active principle (methanol extract) Colchicine was found in higher amount. When Kunapajala was used for Brinjal (Solanum melongena),it produced large number of branches, higher yield, fruits with lesser seeds and lower susceptibility to diseases when compared with plants grown with artificial fertilizer. Similarly for mango, coconut, chilly, paddy, vegetables etc similar results have been found..$^{10}$ Thus, Kunapajala by virtue of its behaviour as growth regulator has been effective in increasing the leaf area, higher yield of flowers and fruits as well as phytoconstituents.

Some major centers carrying out Vrikshayurveda-related work are CIKS, Chennai, Asian Agri-History Foundation (AAHF), Secunderabad and National Institute of Vrikshayurveda, Jhansi. Prof. Nene and his group at the AAHF are promoting Vrikshayurveda in a big way. CIKS, Chennai is involved in promoting organic farming and works along with farmers belonging to various villages in Tamil $\mathrm{Nadu}$. They are also involved in testing and validation of indigenous knowledge of agriculture by rapid assessment of traditional agricultural practices. ${ }^{8}$ As a result of their experiments, as well as that of Indian Council of Agricultural Research, using the modern research procedures, it has been proved that the traditional knowledge is valid beyond doubt.

\section{Conclusion}

The use of pañcagavyam, kunapajala and other procedures mentioned in the various texts can be studied further for efficacy and if found to be suitable can be adopted for the various steps involved in development of organic nursery protocol for medicinal plants. A majority of the raw materials used in these procedures are by-products obtained from other activities and are easily available around us. The procedures are easy and economical too, which is an added advantage. Many of the raw materials listed in the Vrikshayurveda texts, such as flesh and bone of animals, husk, oil cakes, dung and urine of cattle, etc., are waste products and reutilization and recycling of these products will also result in their effective waste management. With the help of ancient texts and model methods of agriculture we can not only scientifically prove the sayings of the text but we could also establish some novel modified methods for the agricultural systems. The proper interpretation and availability of Vrikshayurveda can also play an important role in the field of intercropping and put forward for the use of organic fertilizers and can play a crucial role to build the eco friendly environment. An attempt has been made to compile the traditional methods of conservation and preservation of medicinal plants. It is hoped that the ancient wisdom coupled with modern technology would benefit the mankind.

\section{Acknowledgements}

None.

\section{Conflict of interest}

Author declares there is no conflict of interest towards the manuscript.

\section{References}

1. Mallika Dev. Indian Culture and Lifestyle for Environment Conservation: a Path Towards Sustainable Development International Journal on Emerging Technologies. 2017;8(1):6-260.

2. https://www.infinityfoundation.com/mandala

3. Rutesh R, Shah, Patel RS. Study of Various Plant Species Useful in Each Nakshatra for Human Society. International Journal of Scientific and Research Publications. 2014;4(1):1-10.

4. Ramachandran CK. Vrikshayurveda (Arboreal Medicine in Ancient India). Anc Sci Life. 1984;4(2):110-111.

5. Srikanth N. The science of plant life (Vriksha ayurveda) in archaic literature: an insight on botanical, agricultural and horticultural aspects of ancient India. World Journal of Pharmacy and Pharmaceutical Sciences. 2015;4(6):388

6. Sharma PV. Caraka Samhita, Vimanasthana, Choukambha Orientalia. Varanasi: Chapter Charakasamhita, Kalpasthana -1/10); 1983.

7. Worthington V. Nutritional quality of organic versus conventional fruits, vegetables, and grains. J Altern Complement Med. 2001;7(2):161-173.

8. Suresh G, Haridasan K, Krishnamurthy KV. Relevance of Vṛșāyurveda and other traditional methods for organic production of nursery seedlings of useful plants. Anc Sci Life. 2013;33(1):60-70. 
9. Gangadhar T. Aralelimath, Effects of Vrikshayurveda and modern techniques on germination of bakuchi (psoralea corylifolia linn.). Belagavi, Karnataka, India: A comparative study KLE University; 2006.

10. Bhat Savitha D. Importance of Kunapajala (traditional liquid organic manure) of Vrikshayurveda in medicinal plant cultivation. GJRMI. 2012;1(7):272-279.

11. Vermeer IT, Pachen DM, Dallinga JW, et al. Volatile N-nitrosamine formation after intake of nitrate at the ADI level in combination with an amine-rich diet. Environ Health Perspect. 1998;106(8):459-463.
12. Brajeshwar. Effect of different agronomic practices on Senna (Cassia angustifolia Vahl). M.Sc. dissertation, Jamnagar, India: Gujarat Ayurved University; 2002.

13. Asha KV. Comparative pharmacognostic and pharmacological evaluation of Langali (Gloriosa superba Linn. Ph D Thesis, Jamnagar, India: Gujarat Ayurved University; 2006. 